\title{
Evaluation of Some Faba Bean Genotypes Under Natural Infection with Chocolate Spot and Rust Diseases
}

\section{Marwa Kh A Mohamed ${ }^{1 *}$ and AM El-Bakery ${ }^{2}$}

${ }^{1}$ Field Crops Research Institute, Agricultural Research Center, Egypt

${ }^{2}$ Plant Pathology Research Institute, Agricultural Research Center, Egypt

*Corresponding Author: Marwa Kh A Mohamed, Field Crops Research Institute, Agricultural Research Center, Egypt.

DOI: 10.31080/ASAG.2020.04.0876
Received: July 08, 2020

Published: July 23, 2020

(C) All rights are reserved by Marwa Kh $\mathbf{A}$

Mohamed and AM El-Bakery.

\begin{abstract}
A two year study was conducted at Sakha Agricultural Research Station, Kafr EL-Sheikh Governorate during 2017/2018 and 2018/2019 seasons. The objective of this study was to evaluate productivity of fifteen faba bean genotypes under natural infections with chocolate spot and rust diseases. Faba bean genotypes (Giza 40, Atona, Giza 3, Sakha 1, Misr 1, Santamora, Misr 3, Giza 843, Sakha 3, Sakha 4, Nubaria 1, L 1, L 2, L 3 and L 4) were randomly distributed in a randomized complete block design with three replicates. The results showed that faba bean genotypes Santamora, L2, Giza 843, Sakha 4, and Sakha 3 showed higher resistance to rust and chocolate spot diseases. This was positively reflected on seed yield in both seasons. However, the reverse was true for Giza 40 and Atona genotypes. A significant positive correlation was obtained between flowering or maturity date and each of rust and chocolate spot diseases. There is a highly negative correlation between days to $50 \%$ flowering or maturity date and each of number of pods per plant, seed weight per plant and seed yield per ha. There is a negative correlation between rust or chocolate spot disease and each of number of pods per plant, seed weight per plant and seed yield per ha. Conversely, there is a positive correlation between number of pods per plant and each of seed weight per plant and seed yield per ha. This study indicated that Santamora, L2, Giza 843, Sakha 4 , and Sakha 3 genotypes could be grown to tolerate rust and chocolate spot diseases coincided with high productivity under Sakha region conditions.
\end{abstract}

Keywords: Faba Bean Genotypes; Chlorophyll; Rust Disease; Chocolate Spot Disease; Simple Correlation; Seed Yield

\section{Introduction}

Faba beans (Vicia faba L.) is important for soil fertility, human nutrition as a good source of vegetarian protein [1]. It plays an important role in world agriculture, owing to its high protein content, ability to fix atmospheric nitrogen, capacity to grow and yield well on marginal lands [2]. It is known that the protein content of this crop is higher than other common food legumes [3]. It is the sixth most important grain legume with 4.3 million tonnes of annual production worldwide [4]. However, in Egypt, the cultivated area in 2017 reached about 32 thousand ha with an average productivity of 3.46 ton/ha, according to FAOSTAT [5].

Unfortunately, faba bean production is affected by different factors such as foliar diseases. Ibrahim., et al. [6] reported that foliar diseases, i.e. leaf spots (by Botrytis sp., Stemphylium botryosum and Altenaria tenuis) and rust (by Uromyces fabae) are the limit- ing factors for faba bean production in the northern parts of Egypt. Chocolate spot (Botrytis fabae Sard.) appears as lesions on flowers, leaves and stems with oblong elliptical of reddish to chocolate brown colour, with darker margins that are fairly defined. As lesions increase in number, generally on the upper leaf side, they may remain small expand or merge [7]. The infection by rust appears as a minute, slightly raised, white to cream-colored spots on leaves and to a lesser extent on stems. As spots enlarge the epidermis ruptures, releasing masses of dark drown spores (urediospores) to form characteristic pustules (uredia). The pustules are often surrounded by a ring of yellow tissue. On highly susceptible cultivars, rust can build up rapidly until most of the leaves are covered with pustules. Severely infected leaves rapidly dry up and premature defoliation may occur [8]. According to Khalil., et al. [9], the screening may be conducted either under natural epidemic fields especially at Sakha station or in the greenhouse using artificial infection tech- 
niques. Protecting plants against the two studied diseases by using fungicides has been complicated by the development of fungicidal resistance and/or adverse effect on growth and productivity of the host plant, as well as on the accompanying microflora [10].

The genetic improvement of desired traits via breeding significantly depends on genetic variation in those traits. There is therefore an urgent need to collect and evaluate local genetic resources that can be used in well-designed breeding programs as donors of valuable features in the development of new improved varieties. About forty decades ago, Nassib., et al. [11] claimed that the faba bean breeding program in Egypt aimed to screen for foliar disease resistance, as well as investigate the potential of introductions. In the middle and Near east, yield losses reached about $50-70 \%$ in the case of rust disease [12] and $60-80 \%$ in the case of chocolate spot disease [13]. Susceptible cultivars are usually subjected to foliar damage that limit photosynthetic activity and in turn reduce productivity $[14,15]$. Accordingly, genetic resistance could be considered the most desirable control method since it is less costeffective and environmentally safe than the use of chemicals. Thus, many resistance sources and their associates have been found in different legumes including faba bean $[16,17]$. Therefore, shifting from traditional cultivars to improved ones could enhance faba bean yield by about 18\% in Egypt [18].

However, changes in environmental conditions should be taken into consideration when evaluating disease-resistant genotypes where Sinha and Ghildiyal [19] found that chlorophyll content can be taken as an index of the extent of reduction in the effective green area. The highest values of chlorophyll $(a / b)$ were recorded in leaves of Sakha 2 followed by Nubaria 1 and Sakha 3, meanwhile, Sakha 3 and Sakha 4 recorded the highest values of seed yield per plant, 100-seed weight and seed yield per unit area compared with the other cultivars [20]. So, it is obvious that the disease can reduce the photosynthetic activity in leaves and ultimately lead to lower yield [21]. Consequently, faba bean yields and disease resistance are affected significantly by weather and soil conditions as mentioned by Podlesny., et al. [22]. Particularly, Waly., et al. [23] reported that the resistant genotypes may produce high yield under low and moderate infection of foliar diseases but in the high infections, yield will be decreased in the resistant and susceptible genotypes together.

\section{Aim of the Study}

The main objective of the present study was to evaluate fifteen faba bean genotypes for identifying reliable resistant ones to chocolate spot and rust diseases under natural field infections.

\section{Materials and Methods}

A two year study was conducted at Sakha Agricultural Research Station in 2017/2018 and 2018/2019 seasons to evaluate fifteen faba bean genotypes for resistance to chocolate spot and rust diseases under natural infections. Faba bean genotypes were Giza 40, Atona, Giza 3, Sakha 1, Misr 1, Santamora, Misr 3, Giza 843, Sakha 3, Sakha 4, Nubaria 1, L 1, L 2, L 3 and L 4 (Table 1). Rice was the preceding summer crop in both seasons.

\begin{tabular}{|c|c|}
\hline Faba bean genotype & Pedigree \\
\hline \multirow[t]{2}{*}{ Giza 40} & An individual plant selection from \\
\hline & Rebaya 40 \\
\hline Atona & Introduced from Spain \\
\hline Giza 3 & Giza 1 x Dutch 29 \\
\hline Sakha 1 & Giza 716 x 620/283/85 \\
\hline \multirow[t]{3}{*}{ Misr 1} & Derived from (Giza $3 \times 123 \mathrm{~A} / 45 / 76$ ) \\
\hline & $\mathrm{x}(62 / 1570 / 66 /$ G.2) $\mathrm{x}(\mathrm{Romi} \mathrm{x}$ \\
\hline & Habashi) \\
\hline Santamora & Introduced from Spain \\
\hline Misr 3 & Line 667 x ( Cairo 241 x Giza 461 ) \\
\hline Giza 843 & Cross 461 x Cross 561 \\
\hline \multirow[t]{3}{*}{ Sakha 3} & Promising line 716/402/2001 \\
\hline & derived from cross 716 (Giza 461 \\
\hline & x503/453/83) \\
\hline Sakha 4 & Sakha 1 X Giza 3 \\
\hline Nubaria 1 & (Reina blanca) introduced from Spain \\
\hline L 1 & Giza716 x ILB5346-Ec \\
\hline $\mathrm{L} 2$ & Nubaria3 xNubaria2 \\
\hline L 3 & Nubaria3 x Sakha1 \\
\hline $\mathrm{L} 4$ & (Giza40 xGiza3) x Giza40 \\
\hline
\end{tabular}

Table 1: The common names and pedigree of the studied faba bean genotypes.

Genotypes were arranged on randomized complete block deign with three replicates. The experimental unit included three ridges $60 \mathrm{~cm}$ apart, and 3 meters long occupying an area of $5.4 \mathrm{~m}^{2}$. Calcium super phosphate $\left(15.5 \% \mathrm{P}_{2} \mathrm{O}_{5}\right)$ was added during soil preparation at the rate of $357 \mathrm{~kg} / \mathrm{ha}$. The studied faba bean genotypes were planted on November $2^{\text {nd }}$ and $13^{\text {th }}$ in 2017 and 2018 seasons, respectively, on both sides of the ridges in hills distanced $25 \mathrm{~cm}$ with two plants per hill. All normal agricultural practices were performed. Mineral nitrogen and potassium fertilizers were added at 35.7 and $119 \mathrm{~kg} / \mathrm{ha}$, respectively, at the first irrigation. 
Studied traits

Meteorological data

Meteorological data of Kafr El-Sheikh governorate, starting in November to the end of April 2017/2018 and 2018/2019 seasons were recorded by Rice Research and Training Center (RRTC), Sakha Agriculture Research Station are shown in table 2.
Plant phenology

It represents science of developmental occurrences in plants. It refers to the time patterns associated with developmental stages or sub-periods of plants as affected by environment. Evaluation of phenological duration periods of crop was studied in the field for days to $50 \%$ flowering.

\begin{tabular}{|c|c|c|c|c|c|c|c|c|}
\hline \multirow{2}{*}{ Month } & \multicolumn{2}{|c|}{ Maximum temperature $\left({ }^{\circ} \mathrm{C}\right)$} & \multicolumn{2}{|c|}{ Minimum temperature $\left({ }^{\circ} \mathrm{C}\right)$} & \multicolumn{2}{|c|}{ Relative humidity (\%) } & \multicolumn{2}{|c|}{$\begin{array}{l}\text { Solar radiation } \\
\left(\text { Mega joule } / \mathbf{m}^{2} \text { ) }\right.\end{array}$} \\
\hline & First season & Second season & First season & Second season & First season & Second season & First season & Second season \\
\hline November & 24.00 & 25.32 & 10.50 & 15.46 & 86.70 & 89.20 & 13.0 & 13.0 \\
\hline December & 20.19 & 21.38 & 6.44 & 10.57 & 86.00 & 84.74 & 15.2 & 15.0 \\
\hline January & 18.16 & 19.20 & 8.35 & 7.60 & 77.50 & 90.95 & 15.0 & 15.2 \\
\hline February & 17.54 & 20.80 & 9.57 & 8.95 & 75.61 & 90.22 & 15.5 & 15.5 \\
\hline March & 19.22 & 21.71 & 10.08 & 10.79 & 84.65 & 83.14 & 15.3 & 15.0 \\
\hline April & 21.58 & 23.03 & 11.54 & 12.33 & 81.64 & 85.01 & 15.1 & 15.0 \\
\hline Average & 20.11 & 21.90 & 9.41 & 10.95 & 85.35 & 83.87 & 14.85 & 14.78 \\
\hline
\end{tabular}

Table 2: Meteorological data of Kafr El-Sheikh governorate in 2017/2018 and 2018/2019 seasons.

Rice Research and Training Center (RRTC), Sakha Agriculture Research Station, Monthly weather observations.

Average relative humidity (\%), at 7.30 and 13.30 hour.

\section{Chlorophyll content}

85 days after planting, leaf chlorophyll a and b contents were analyzed by Crop Physiology Research Department at Sakha Research Station, ARC: The leaves (blade only) from three plants were separated, dried, in an oven at $75^{\circ} \mathrm{C}$ until reaching a constant mass (approximately 48h), then weighed. Leaf chlorophyll content was determined according to Holden [24]. Total chlorophyll content was calculated by adding chlorophyll a to chlorophyll b.

\section{Foliar disease assessment}

Rust disease: The disease severity of rust was recorded at 85 and 115 days after planting according to the standard scale suggested by Bernier., et al. [8] as follows: 1 = No pustules or very small non sporulating flecks (highly resistant), 3 = Few scattered pustules covering less than $1 \%$ of leaf area, and few or no pustules on stem (resistant), 5 = Pustules common on leaves covering 1-4\% of leaf area, little defoliation and some pustules on stem (moderately resistant), 7 = Pustules very common on leaves covering $4-8 \%$ of leaf area, some defoliation and many pustules on stem (susceptible) and $9=$ Extensive pustules on leaves, petioles and stems covering $8-10 \%$ of leaf area, many dead leaves and severe defoliation (highly susceptible).
Chocolate spot disease: The disease severity of chocolate spot was estimated at 85 and 115 days after planting under natural infection using the scale of Hanounik [25] and Bernier., et al. (1993) as follows: $1=$ No disease symptoms or very small specks (highly resistant, $0-2.0 \%$ ), 3=Few small discrete lesions (resistant, 2.0 15.0\%), 5 = Some coalesced lesions with some defoliation (moderately resistant, $15.0-40.0 \%$ ), 7 = Large coalesced sporulating lesions, 50\% defoliation and some dead plants (susceptible, 50 $80 \%$ ) and 9=Extensive lesions on leaves, stems and pods, severe defoliation, heavy sporulation stem girdling, blackening and death of more than $80 \%$ of plants (highly susceptible, 80 - 100\%).

Maturity date, seed yield and its attributes

At harvest, plant samples were taken at random from each plot to determine maturity date (day), plant height (cm), number of branches per plant, number of pods per plant and seed weight per plant (g). Seed yield per ha was recorded on plot basis then converted into ton/ha.

Simple correlation coefficient

Phenotypic correlation coefficients were calculated from the combined data across the two seasons for all the studied traits by PLABSTAT program. 
Statistical analysis

The measured variables were analyzed by ANOVA using MSTATC statistical package [26]. Mean comparisons were compared using the least significant difference (L.S.D) test at $0.05 \%$ level of probability [27].

Results and Discussion

Significance of variation sources of faba bean traits

Sum squares of faba bean traits showed that faba bean genotype effect remained significant at $1 \%$ of chlorophyll a, total chlorophyll content, foliar diseases, days to $50 \%$ flowering, maturity date, seed weight per plant and seed yield per ha in both seasons (Table 3-5). Differences among faba bean genotypes were significant for chlo-

\begin{tabular}{|l|c|c|c|c|}
\hline \multirow{2}{*}{ S.o.V } & \multirow{2}{*}{ d.f. } & \multicolumn{3}{|c|}{ Chlorophyll content } \\
\cline { 3 - 5 } & & $\begin{array}{c}\text { Chlorophyll } \\
\text { a }\end{array}$ & $\begin{array}{c}\text { Chlorophyll } \\
\text { b }\end{array}$ & $\begin{array}{c}\text { Total } \\
\text { chlorophyll }\end{array}$ \\
\hline \multicolumn{5}{|c|}{ First season } \\
\hline Rep. & 1 & 0.50 N.S. & 0.02 N.S. & 0.31 N.S. \\
\hline Genotype & 14 & $1.79^{* *}$ & $0.68^{*}$ & $2.56^{* *}$ \\
\hline Error & 28 & 0.33 & 0.27 & 0.37 \\
\hline Second season \\
\hline Rep. & 1 & 0.02 N.S. & 0.00 N.S. & 0.03 N.S. \\
\hline Genotype & 14 & $2.59^{* *}$ & $1.00^{* *}$ & 3.69 ** \\
\hline Error & 28 & 0.01 & 0.01 & 0.01 \\
\hline
\end{tabular}

Table 3: Sum squares of chlorophyll traits of the studied faba bean genotypes.

**: Significance at a $1 \%$ level of probability $(\mathrm{p}<0.01)$.

*: Significance at a $5 \%$ level of probability $(0.01=<p<0.05)$.

N.S. Non-Significant ( $p>=0.05)$. rophyll $b$ and number of seeds per plant, and highly significant for plant height and number of pods per plant in only one season. This means that all the studied faba bean genotypes differed in chlorophyll a, chlorophyll b, total chlorophyll content, foliar diseases, days to $50 \%$ flowering, maturity date, seed yields per plant and per ha. This indicates that expected genetic gain from selection for these traits could be fast in this genetic material. The replication effect was not significant at $5 \%$ level of probability for all studied traits. Thus, the consistent response was observed for faba bean genotypes for all studied traits, indicating genotypes could be selected for this area with limited evaluations. These results are in parallel with those observed by El-Rodeny., et al. [28] who found that genotypes significantly differed for growth-related and yield traits, as well as disease resistance traits.

\begin{tabular}{|l|c|c|c|c|c|}
\hline \multirow{2}{*}{ S.o.V } & \multirow{2}{*}{ d.f. } & \multicolumn{2}{c|}{ Rust disease } & \multicolumn{2}{c|}{$\begin{array}{c}\text { Chocolate spot dis- } \\
\text { ease }\end{array}$} \\
\cline { 3 - 6 } & & $\mathbf{8 5 ~ d}$ & $\mathbf{1 1 5} \mathbf{~ d}$ & $\mathbf{8 5 ~ d}$ & $\mathbf{1 1 5 ~ d}$ \\
\hline \multicolumn{6}{|c|}{ First season } \\
\hline Rep. & 2 & 0.00 N.S. & 0.05 N.S. & 0.01 N.S. & 69.30 N.S. \\
\hline Genotype & 14 & $3.04^{* *}$ & $16.00^{* *}$ & $50.80^{* *}$ & $775.14^{* *}$ \\
\hline Error & 28 & 0.07 & 0.07 & 0.28 & 68.75 \\
\hline \multicolumn{7}{|c|}{ Second season } \\
\hline Rep. & 2 & 0.00 N.S. & 0.03 N.S. & 0.40 N.S. & 2.79 N.S. \\
\hline Genotype & 14 & $0.38^{* *}$ & $16.45^{* *}$ & $73.86^{* *}$ & $1463.69 * *$ \\
\hline Error & 28 & 0.00 & 0.13 & 0.30 & 5.19 \\
\hline
\end{tabular}

Table 4: Sum squares of foliar diseases of the studied faba bean genotypes.

**: Significance at a $1 \%$ level of probability $(\mathrm{p}<0.01)$.

*: Significance at a $5 \%$ level of probability $(0.01=<p<0.05)$.

N.S.: Non-Significant ( $\mathrm{p}>=0.05)$.

\begin{tabular}{|l|c|c|c|c|c|c|c|c|c|}
\hline \multicolumn{1}{|c|}{ S.o.V } & d.f. & $\begin{array}{c}\text { Days to 50\% } \\
\text { flowering }\end{array}$ & $\begin{array}{c}\text { Maturity } \\
\text { date }\end{array}$ & $\begin{array}{c}\text { Plant } \\
\text { height }\end{array}$ & $\begin{array}{c}\text { Number of } \\
\text { branch/plant }\end{array}$ & $\begin{array}{c}\text { Number of } \\
\text { pods/plant }\end{array}$ & $\begin{array}{c}\text { Seed yield/ } \\
\text { plant }\end{array}$ & $\begin{array}{c}\text { Seed yield/ } \\
\text { ha }\end{array}$ \\
\hline \multicolumn{7}{|c|}{ First season } \\
\hline Rep. & 2 & 10.55 N.S. & 33.88 N.S. & 9.48 N.S. & 0.08 N.S. & 2.11 N.S. & 25.67 N.S. & 0.04 N.S. \\
\hline Genotype & 14 & $67.69 * *$ & $247.46^{* *}$ & $278.11 * *$ & 0.27 N.S. & $24.39 * *$ & $247.38 * *$ & $1.90 * *$ \\
\hline Error & 28 & 4.60 & 17.22 & 10.86 & 0.44 & 2.46 & 59.94 & 0.16 \\
\hline \multicolumn{7}{|c|}{ Second season } & & & \\
\hline Rep. & 2 & 1.66 N.S. & 13.86 N.S. & 7.22 N.S. & 0.39 N.S. & 16.87 N.S. & 39.40 N.S. & 0.04 N.S. \\
\hline Genotype & 14 & $120.00 * *$ & $217.62^{* *}$ & 190.07 N.S. & 0.28 N.S. & 18.27 N.S. & $330.62 * *$ & $2.84 * *$ \\
\hline Error & 28 & 5.23 & 7.79 & 119.12 & 0.60 & 20.76 & 69.00 & 0.20 \\
\hline
\end{tabular}

Table 5: Sum squares of maturity and flowering dates, seed yield and its attributes of the studied faba bean genotypes.

**: Significance at a $1 \%$ level of probability $(\mathrm{p}<0.01)$. : Significance at a $5 \%$ level of probability $(0.01=<\mathrm{p}<0.05)$.

N.S.: Non-Significant ( $\mathrm{p}>=0.05)$. 
Plant phenology

The results in figure 1 show genotypic variation among the studied faba bean genotypes for days to $50 \%$ flowering in both seasons. Sakha 1, Sakha 4, L3 and Santamora genotypes were earlier in flowering than the other genotypes in both seasons. These results reveal that Sakha 1, Sakha 4, L3 and Santamora genotypes have shorter vegetative growth phase and shorter reproductive phase. Conversely, faba bean genotype Nubaria 1 followed by Atona and L2 were late in flowering in the first season. In the second season, Nubaria 1, L1, L4, Atona and Misr 3 genotypes were late in their flowering.

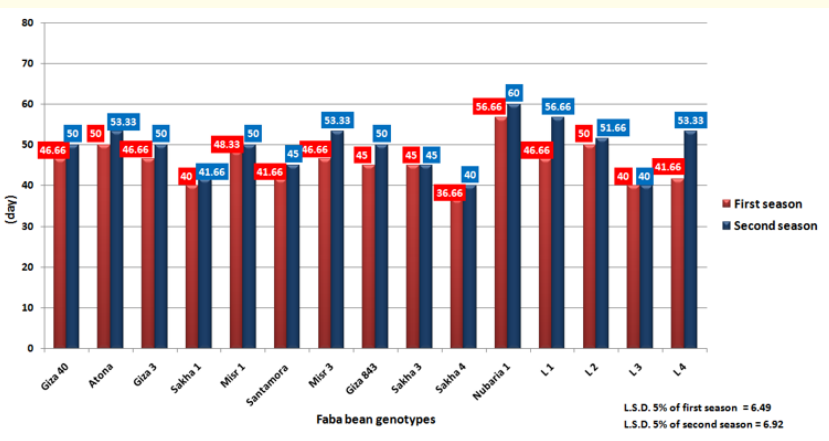

Figure 1: Days to $50 \%$ flowering of of the studied faba bean genotypes in both seasons.

\section{Chlorophyll pigments}

Chlorophyll a, b and their total in leaves were significantly affected by faba bean genotype (Figure 2). Leaves of all faba bean genotypes had higher content of chlorophyll a except two genotypes i.e. Atona and L4 in the first season. However, lower chlorophyll a was observed in leaves of all studied faba bean genotypes, except Santamora, Sakha 4, L1, Giza 40 and Nubaria 1 in the second season. With regard to chlorophyll $b$, leaves of all studied faba bean genotypes showed higher contents of this trait except Sakha 4 in the first season, meanwhile, leaves of all genotypes showed lower contents of chlorophyll b except Misr 1 and Sakha 3 in the second season. On the other hand, leaves of all studied genotypes had higher total chlorophyll, except Atona in the first season. However, leaves of Santamora genotype gave the highest total chlorophyll, meanwhile the reverse was true for Atona compared with the other genotypes in the second season. This may be due to variations in genetic background among genotypes (Table 1) which was translated into the expression and activity of the chlorophyllase enzyme.

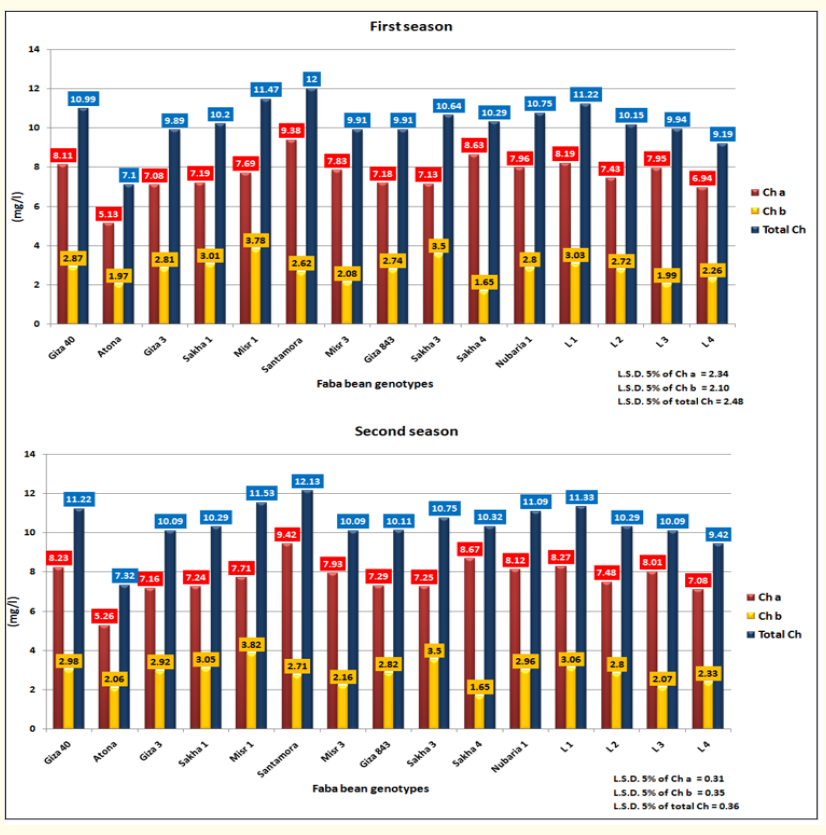

Figure 2: Contents of chlorophyll a, b and total chlorophyll in leaves of fifteen faba bean genotypes in both seasons.

\section{Foliar disease assessment}

Certainly, lifecycle of the a pathogen vary from region to another, where it is associated with temperature and moisture conditions. Rust and chocolate spot diseases can rapidly develop under optimal environmental conditions. Data in figure 3 show that the severity of rust and chocolate spot diseases differed according to differences in climatic conditions between the first and second season. It seems that the spreading of rust and chocolate spot diseases was faster in the second season than the first one under Kafr El-Sheikh governorate conditions. These data show that severity of the diseases was lower in the first season than the second one. Moreover, the severity of the diseases was lower in February than March in both seasons. These results could be due to high temperature and low humidity that furnished suitable environmental conditions to enhance pathogen spreading. It is known that increased temperature and decreased relative humidity are the two climatic factors that increase foliar diseases [7]. Also, low solar radiation has positive effects on pathogen activity where ultraviolet radiation in sunlight is the major factor affecting the germination of fungal propagules [29] through damaging DNA and proteins [30].

Accordingly, it seems that temperature above $25^{\circ} \mathrm{C}$ and below 7-8 ${ }^{\circ} \mathrm{C}$ controlled rust and chocolate spot spreading under Kafr ElSheikh governorate conditions. 


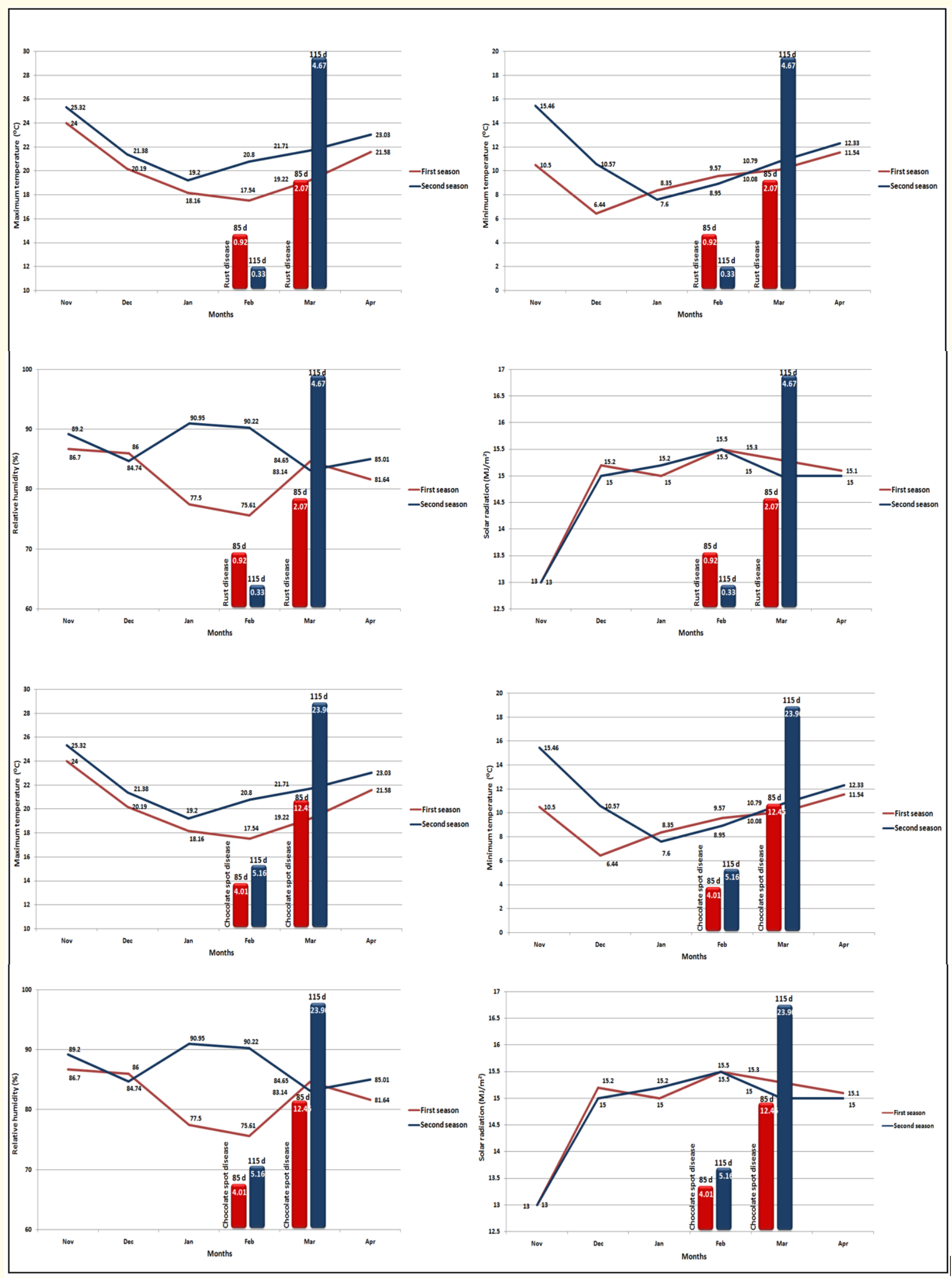

Figure 3: Meteorological data at Sakha region governorate and its relation to foliar disease severity. 
Consequently, it is expected that rust or chocolate spot pathogen would be unable to traverse the leaf surface to penetrate the plant by stability air temperature and relative humidity and solar radiation from a month to another. According to Pulse Breeding Australia [31], rust can occur from early- to mid-spring on, and is favoured by warm temperatures. Also, chocolate spot is favoured by warm and humid conditions that extend for four to five days. Moreover, Yitayih and Azmeraw [32] mentioned that chocolate spot disease results in heavy premature defoliation and under warm moist conditions crop lodging may occur.

\section{Rust disease}

Data in table 6 showed that rust disease severity differed among the studied faba bean genotypes under natural field conditions in both seasons. At 85 days after sowing, leaves of faba bean cultivar Giza 40 had the highest rust disease severity (4.25\%) compared with the other genotypes in the first season.

\begin{tabular}{|c|c|c|c|c|}
\hline \multirow{3}{*}{$\begin{array}{c}\begin{array}{c}\text { Faba bean } \\
\text { genotype }\end{array} \\
\text { Giza } 40\end{array}$} & \multirow{2}{*}{\multicolumn{2}{|c|}{$\begin{array}{l}85 \text { days }(\%) \\
\text { First season }\end{array}$}} & \multirow{2}{*}{\multicolumn{2}{|c|}{$\begin{array}{c}115 \text { days }(\%) \\
\text { First season }\end{array}$}} \\
\hline & & & & \\
\hline & 4.25 & Susceptible & 9.76 & $\begin{array}{c}\text { Highly } \\
\text { susceptible }\end{array}$ \\
\hline Atona & 1.02 & $\begin{array}{l}\text { Moderately } \\
\text { resistant }\end{array}$ & 2.00 & $\begin{array}{l}\text { Moderately } \\
\text { resistant }\end{array}$ \\
\hline Giza 3 & 1.27 & $\begin{array}{l}\text { Moderately } \\
\text { resistant }\end{array}$ & 3.74 & $\begin{array}{l}\text { Moderately } \\
\text { resistant }\end{array}$ \\
\hline Sakha 1 & 0.27 & Resistant & 1.09 & $\begin{array}{l}\text { Moderately } \\
\text { resistant }\end{array}$ \\
\hline Misr 1 & 1.02 & $\begin{array}{l}\text { Moderately } \\
\text { resistant }\end{array}$ & 2.07 & $\begin{array}{l}\text { Moderately } \\
\text { resistant }\end{array}$ \\
\hline Santamora & 1.13 & $\begin{array}{l}\text { Moderately } \\
\text { resistant }\end{array}$ & 2.60 & $\begin{array}{l}\text { Moderately } \\
\text { resistant }\end{array}$ \\
\hline Misr 3 & 0.71 & Resistant & 1.23 & $\begin{array}{l}\text { Moderately } \\
\text { resistant }\end{array}$ \\
\hline Giza 843 & 0.16 & Resistant & 0.31 & Resistant \\
\hline Sakha 3 & 0.50 & Resistant & 1.17 & $\begin{array}{l}\text { Moderately } \\
\text { resistant }\end{array}$ \\
\hline Sakha 4 & 0.26 & Resistant & 0.79 & Resistant \\
\hline Nubaria 1 & 0.81 & Resistant & 1.16 & $\begin{array}{l}\text { Moderately } \\
\text { resistant }\end{array}$ \\
\hline L 1 & 1.06 & $\begin{array}{l}\text { Moderately } \\
\text { resistant }\end{array}$ & 1.27 & $\begin{array}{l}\text { Moderately } \\
\text { resistant }\end{array}$ \\
\hline L 2 & 0.08 & Highly resistant & 0.65 & Resistant \\
\hline L 3 & 0.22 & Resistant & 0.81 & Resistant \\
\hline L 4 & 1.13 & $\begin{array}{c}\text { Moderately } \\
\text { resistant }\end{array}$ & 2.50 & $\begin{array}{l}\text { Moderately } \\
\text { resistant }\end{array}$ \\
\hline L.S.D. 0.05 & & 0.83 & & 0.83 \\
\hline
\end{tabular}

\begin{tabular}{|c|c|c|c|c|}
\hline \multirow{2}{*}{\begin{tabular}{|l|}
$\begin{array}{l}\text { Faba bean } \\
\text { genotype }\end{array}$ \\
Giza 40
\end{tabular}} & \multicolumn{2}{|c|}{ Second season } & \multicolumn{2}{|c|}{ Second season } \\
\hline & 1.02 & $\begin{array}{c}\text { Moderately resis- } \\
\operatorname{tant}\end{array}$ & 9.33 & $\begin{array}{c}\text { Highly suscep- } \\
\text { tible }\end{array}$ \\
\hline Atona & 0.91 & Resistant & 7.54 & Susceptible \\
\hline Giza 3 & 1.13 & $\begin{array}{l}\text { Moderately resis- } \\
\text { tant }\end{array}$ & 10.12 & $\begin{array}{l}\text { Highly suscep- } \\
\text { tible }\end{array}$ \\
\hline Sakha 1 & 0.17 & Resistant & 4.50 & Susceptible \\
\hline Misr 1 & 0.18 & Resistant & 4.04 & Susceptible \\
\hline Santamora & 0.12 & Resistant & 3.50 & $\begin{array}{l}\text { Moderately } \\
\text { resistant }\end{array}$ \\
\hline Misr 3 & 0.17 & Resistant & 3.95 & $\begin{array}{l}\text { Moderately } \\
\text { resistant }\end{array}$ \\
\hline Giza 843 & 0.17 & Resistant & 3.26 & $\begin{array}{l}\text { Moderately } \\
\text { resistant }\end{array}$ \\
\hline Sakha 3 & 0.22 & Resistant & 3.84 & $\begin{array}{l}\text { Moderately } \\
\text { resistant }\end{array}$ \\
\hline Sakha 4 & 0.20 & Resistant & 3.80 & $\begin{array}{l}\text { Moderately } \\
\text { resistant }\end{array}$ \\
\hline Nubaria 1 & 0.18 & Resistant & 3.92 & $\begin{array}{l}\text { Moderately } \\
\text { resistant }\end{array}$ \\
\hline L 1 & 0.16 & Resistant & 3.77 & $\begin{array}{l}\text { Moderately } \\
\text { resistant }\end{array}$ \\
\hline L 2 & 0.12 & Resistant & 2.84 & $\begin{array}{l}\text { Moderately } \\
\text { resistant }\end{array}$ \\
\hline L 3 & 0.13 & Resistant & 3.06 & $\begin{array}{l}\text { Moderately } \\
\text { resistant }\end{array}$ \\
\hline L 4 & 0.15 & Resistant & 2.64 & $\begin{array}{l}\text { Moderately } \\
\text { resistant }\end{array}$ \\
\hline L.S.D. 0.05 & & 0.13 & & 1.09 \\
\hline
\end{tabular}

Table 6: Rust disease severity of the studied faba bean genotypes at 85 and 115 days after planting.

On the other hand, lower disease severity was observed on leaves of faba bean genotypes L2 (0.08\%) and Giza 843 (0.16\%), L3 (0.22\%), Sakha 4 (0.26\%), Sakha $1(0.27 \%)$, Sakha 3 (0.50\%), Misr $3(0.71 \%)$ and Nubaria $1(0.81 \%)$. Meanwhile, faba bean genotypes Misr 1 (1.02\%), Atona (1.02\%), L1 (1.06\%), L4 (1.13\%), Santamora (1.13\%) and Giza $3(1.27 \%)$ were moderately resistant to rust infection at 85 days after sowing in the first season.

In the second season, leaves of faba bean cultivars Giza 3 and Giza 40 were moderately resistant to rust infection (1.13 and $1.02 \%$, respectively). However, the other genotypes were resistant to this disease at 85 days after sowing. 
Leaves of faba bean Giza 40 cultivar showed the highest disease severity of rust (9.76\%), meanwhile, disease severity on Giza 843 (0.31\%), L2 (0.65\%), Sakha 4 (0.79\%), L3 (0.81\%) and Sakha 1 $(1.09 \%)$ was ranging from lower to moderate, followed by Nubaria 1 (1.16\%), Sakha 3 (1.17\%), Misr 3 (1.23\%), L1 (1.27\%), Atona (2.00\%), Misr 1 (2.07\%), L4 (2.50\%) and Santamora (2.60\%), then Giza 3 cultivar came in later (3.74\%) at 115 days after sowing in the first season. At 115 days after sowing, leaves of Giza 3 and Giza 40 cultivars showed higher rust severity (10.12 and 9.33\%, respectively), followed by Atona (7.54\%), then Sakha 1 (4.50\%) and Misr 1 (4.04\%) cultivars. However, disease severity on faba bean genotypes L4 (2.64\%), L2 (2.84\%), L3 (3.06\%), Giza 843 (3.26\%), Santamora (3.50\%), L1 (3.77\%), Sakha 4 (3.80\%), Sakha 3 (3.84\%), Nubaria 1 (3.92\%) and Misr 3 (3.95) were moderate in the second season.

Generally, it seems that most of the studied faba bean genotypes were resistant to rust infection, and this effect probably differed directly or indirectly by seasonal shift due to fluctuating climatic conditions at 85 and 115 days after sowing (Table 2 and figure 3). It is likely that flowering period of faba bean genotypes Atona, Giza 3, Misr 1, Santamora, Giza 843, Sakha 3, Sakha 4, Nubaria 1, L1, L2, L3 and L4 (Figure 1), and chlorophyll content in their leaves at 85 days after sowing in the first season (Figure 2) played an important role for maintaining their resistance or susceptibility to rust infection. With regard to flowering period, leaves of Giza 40 cultivar had high chlorophyll content did not enhance its resistance to rust infection at 85 through 115 days after sowing in both seasons. With respect to faba bean genotype Santamora, this genotype flowered earlier and leaves had higher contents of chlorophyll $a, b$ and total chlorophyll that may be contributed positively to the stability of its resistance to rust infection at 85 to 115 days after sowing in the first season. Accordingly, it is expected that these traits maintained resistance of faba bean genotype Santamora to rust infection from 85 to 115 days after sowing in the second one. Meanwhile, higher contents of the studied chlorophyll pigments in leaves of faba bean cultivars Giza 3 and Misr 1 regardless their flowering period probably maintained their resistance to rust infection from 85 to 115 days after sowing in the first season. Thus, it seems that lower content of chlorophyll $b$ with longer flowering period of faba bean cultivar Misr 3 contributed largely in its susceptibility to rust infection at 85 to 115 days after sowing in the second season.

Regardless chlorophyll pigments, it is likely that longer flowering period of faba bean cultivar Giza 3 interacted negatively with environmental conditions to enhance susceptibility of this cultivar to rust infection at 85 to 115 days after sowing in the second season. Regardless flowering period, leaves of faba bean cultivar Giza 843 that had higher contents of the studied chlorophyll pigments could be maintained its resistance to rust infection at 85 to 115 days after sowing in the first season. However, it is likely that lower contents of chlorophyll a and $b$ in leaves of faba bean cultivar Giza 843 did not play a role in its resistance to rust infection at 85 to 115 days after sowing in the second season. Regardless flowering period, leaves of faba cultivar Sakha 3 that had higher contents of the studied chlorophyll pigments could have maintained its resistance to rust infection at 85 to 115 days after sowing in the first season. Thus, it seems that higher contents of the studied chlorophyll pigments in leaves of faba cultivar Sakha 3 maintained its resistance to rust infection at 85 to 115 days after sowing in the second season. With respect to faba bean cultivar Sakha 4, plants of this cultivar flowered earlier with higher leaf content of chlorophyll a and total chlorophyll. This may be contributed positively in stability of resistance to rust infection at 85 to 115 days after sowing in the first season. Accordingly, it is expected that lower chlorophyll $b$ in leaves of faba bean cultivar Sakha 4 did not play a negative role in its resistance to rust infection at 85 to 115 days after sowing in the second season. Meanwhile, higher content of the studied chlorophyll pigments in leaves of faba bean cultivar Nubaria 1 with its longer flowering period probably maintained its resistance to rust infection at 85 to 115 days after sowing in the first season. Thus, it seems that lower content of chlorophyll b with longer flowering period of faba bean cultivar Nubaria 1 did not play a negative role in its resistance to rust infection at 85 to 115 days after sowing in the second season. Although flowering of faba bean genotype L1 was late in the first season (Figure 1), it seems that higher content of chlorophyll pigments in its leaves maintained its resistance to rust infection at 85 to 115 days after sowing in the first season. Consequently, it is expected that these traits maintained resistance of L1 genotype to rust infection at 85 to 115 days after sowing in the second season. With respect to faba bean genotype L2, higher content of the studied chlorophyll pigments in leaves of this genotype with its longer flowering period played positively in its resistance to rust infection at 85 to 115 days after sowing in the first season. Thus, it seems that flowering period of L4 genotype interacted positively with lower content of chlorophyll a and b to contribute largely in its resistance to rust infection at 85 to 115 days after sowing in the second season. L3 genotype flowered early with high leaf content of chlorophyll a and total chlorophyll. This may be contributed positively in stability of its resistance to rust infection at 85 to 115 days after sowing in the first season. 
Accordingly, it is expected that shorter flowering period had important role to overcome lower content of chlorophyll a and $b$ in leaves of faba bean genotype L3 for enhancing its resistance to rust infection in the second season. With regard to Atona genotype, it was late in flowering and had high content of chlorophyll $\mathrm{b}$ in its leaves. This may be contributed positively in stability of its resistance to rust infection at 85 to 115 days after sowing in the first season. Accordingly, it is expected that lower content of chlorophyll a and total chlorophyll played a major role in susceptibility of Atona genotype to rust infection at 85 to 115 days after sowing in the second season. Meanwhile, faba bean genotype L4 flowered late with high content of chlorophyll $b$ and total chlorophyll that could be maintained its resistance to rust infection at 85 to 115 days after sowing in the first season. Thus, it seems that these traits contributed largely in resistance of L4 genotype to rust infection in the second season. These results indicate that faba bean genotypes viz., Giza 40, Atona, Giza 3, Sakha 1 and Misr 3 could not maintain their genetic potential to resist rust infection at 85 to 115 days after sowing under natural field conditions in both seasons, indicating one year should not be satisfied when depending on those genotypes in breeding programs. So, it may be possible that differences among the studied faba bean genotypes with climatic conditions are the key elements that determine the epidemic development of rust disease. No virulent pathogen strain can induce disease on susceptible cultivars if climatic conditions are not favorable [33]. Thus, these factors greatly influence the number of pustules. These results are in harmony with those obtained by Waly., et al. [23] who indicated that faba bean cultivars Giza 843 and Giza 40 had higher chlorophyll a and b contents compared with the other cultivars under common fungal diseases.

\section{Chocolate spot disease}

Data in table 7 show that the disease severity with chocolate spot on the studied faba bean genotypes was different under natural field conditions in both seasons. At 85 days after sowing, leaves of Atona (12.66\%), Giza 40 (11.54\%) and Giza 3 (11.49\%), Misr 3 (2.91\%), Misr 1 (2.50\%), Nubaria 1 (2.41\%), Giza 843 (2.25\%), L4 (2.25\%), Santamora (2.20\%) and L1 (2.16\%) were considered resistant. Meanwhile faba bean genotypes L3 (0.99\%), L2 (1.33\%), Sakha $1(1.66 \%)$, Sakha $4(1.87 \%)$ and Sakha $3(1.95 \%)$ were considered highly resistant to this disease in the first season.

In the second season, faba bean cultivar Giza 40 (16.79\%) was moderately resistant to chocolate spot disease, followed by faba bean genotypes Atona (12.95\%), Giza 3 (11.45\%), Misr 1 (8.66\%),

\begin{tabular}{|c|c|c|c|c|}
\hline \multirow{3}{*}{\begin{tabular}{|l|}
$\begin{array}{l}\text { Faba bean } \\
\text { genotype }\end{array}$ \\
Giza 40 \\
\end{tabular}} & \multicolumn{2}{|c|}{85 days $(\%)$} & \multicolumn{2}{|c|}{115 days $(\%)$} \\
\hline & \multicolumn{2}{|c|}{ First season } & \multicolumn{2}{|c|}{ First season } \\
\hline & 11.54 & Resistant & 65.70 & Susceptible \\
\hline Atona & 12.66 & Resistant & 27.99 & $\begin{array}{l}\text { Moderately } \\
\text { resistant }\end{array}$ \\
\hline Giza 3 & 11.49 & Resistant & 17.49 & $\begin{array}{l}\text { Moderately } \\
\text { resistant }\end{array}$ \\
\hline Sakha 1 & 1.66 & Highly resistant & 2.81 & Resistant \\
\hline Misr 1 & 2.50 & Resistant & 8.24 & Resistant \\
\hline Santamora & 2.20 & Resistant & 6.91 & Resistant \\
\hline Misr 3 & 2.91 & Resistant & 10.29 & Resistant \\
\hline Giza 843 & 2.25 & Resistant & 6.52 & Resistant \\
\hline Sakha 3 & 1.95 & Highly resistant & 5.19 & Resistant \\
\hline Sakha 4 & 1.87 & Highly resistant & 5.14 & Resistant \\
\hline Nubaria 1 & 2.41 & Resistant & 7.28 & Resistant \\
\hline L 1 & 2.16 & Resistant & 7.41 & Resistant \\
\hline L 2 & 1.33 & Highly resistant & 7.53 & Resistant \\
\hline L 3 & 0.99 & Highly resistant & 1.51 & Highly resistant \\
\hline $\mathrm{L} 4$ & 2.25 & Resistant & 6.87 & Resistant \\
\hline L.S.D. 0.05 & \multicolumn{2}{|r|}{1.61} & \multicolumn{2}{|r|}{25.09} \\
\hline $\begin{array}{l}\text { Faba bean } \\
\text { genotype }\end{array}$ & \multicolumn{2}{|c|}{ Second season } & \multicolumn{2}{|c|}{ Second season } \\
\hline Giza 40 & 16.79 & $\begin{array}{l}\text { Moderately } \\
\text { resistant }\end{array}$ & 92.27 & $\begin{array}{c}\text { Highly } \\
\text { susceptible }\end{array}$ \\
\hline Atona & 12.95 & Resistant & 48.66 & Susceptible \\
\hline Giza 3 & 11.45 & Resistant & 31.41 & $\begin{array}{l}\text { Moderately } \\
\text { resistant }\end{array}$ \\
\hline Sakha 1 & 1.66 & Highly resistant & 14.70 & Resistant \\
\hline Misr 1 & 8.66 & Resistant & 30.87 & $\begin{array}{l}\text { Moderately } \\
\text { resistant }\end{array}$ \\
\hline Santamora & 4.63 & Resistant & 24.62 & $\begin{array}{l}\text { Moderately } \\
\text { resistant }\end{array}$ \\
\hline Misr 3 & 5.60 & Resistant & 18.49 & $\begin{array}{l}\text { Moderately } \\
\text { resistant }\end{array}$ \\
\hline Giza 843 & 1.18 & Highly resistant & 3.95 & Resistant \\
\hline Sakha 3 & 1.99 & Highly resistant & 10.91 & Resistant \\
\hline Sakha 4 & 0.89 & Highly resistant & 4.08 & Resistant \\
\hline Nubaria 1 & 2.10 & Resistant & 17.83 & $\begin{array}{l}\text { Moderately } \\
\text { resistant }\end{array}$ \\
\hline L 1 & 2.44 & Resistant & 19.04 & $\begin{array}{l}\text { Moderately } \\
\text { resistant }\end{array}$ \\
\hline L 2 & 2.16 & Resistant & 15.24 & $\begin{array}{l}\text { Moderately } \\
\text { resistant }\end{array}$ \\
\hline L 3 & 2.18 & Resistant & 13.49 & Resistant \\
\hline L 4 & 2.83 & Resistant & 12.95 & Resistant \\
\hline L.S.D. 0.05 & & 1.65 & & 6.90 \\
\hline
\end{tabular}

Table 7: Chocolate spot disease severity of the studied faba bean genotypes at 85 and 115 days after sowing. 
Misr 3 (5.60\%), Santamora (4.63\%), L4 (2.83\%), L1 (2.44\%), L3 (2.18\%), L2 (2.16\%) and Nubaria 1 (2.10\%) were resistant to this disease. However, faba bean cultivars Sakha 4 (0.89\%), Giza 843 (1.11\%), Sakha $1(1.66 \%)$ and Sakha $3(1.99 \%)$ were highly resistant at 85 days after sowing. At 115 days after sowing, leaves of faba bean cultivar Giza 40 showed the highest chocolate spot disease severity (65.70\%) compared with the other genotypes in the first season.

Meanwhile, L3 genotype was highly resistant to chocolate spot infection recording $1.51 \%$, followed by faba bean genotypes Sakha 1 (2.81\%), Sakha 4 (5.14\%), Sakha 3 (5.19\%), Giza 843 (6.52\%), L4 (6.87\%), Santamora (6.91\%), Nubaria 1 (7.28\%), L1 (7.41\%), L2 (7.53\%), Misr 1 (8.24\%) and Misr 3 (10.29\%) that were resistant to this disease, then faba bean genotypes Giza 3 (17.49\%) and Atona (27.99\%) came in the last rank at 115 days after sowing in the first season. In the second season, leaves of faba bean cultivar Giza 40 recorded the highest disease severity of chocolate spot (92.27\%), followed by faba bean genotype Atona (48.66\%)\%) compared with the other genotypes at 115 days after sowing. However, faba bean genotypes, Giza 843 (3.95\%), Sakha 4 (4.08\%), Sakha 3 (10.91\%), L4 (12.95\%), L3 (13.49\%) and Sakha 1 (14.70\%) were resistant to chocolate spot infection, followed by L2 (15.24\%), Nubaria 1 (17.83\%), Misr 3 (18.49\%), L1 (19.04\%), Santamora (24.62\%), Misr 1 (30.87\%) and Giza 3 (31.41\%) genotypes that were moderately resistant to chocolate spot disease at 115 days after sowing in the second season.

Generally, it seems that most of the studied faba bean genotypes have resistance to chocolate spot disease, and this is directly or indirectly affected by seasonal climatic conditions (Table 2 and figure 3). Faba bean genotype Giza 40 was more susceptible to chocolate spot infection than the other genotypes in both seasons, followed by faba bean genotype Atona in the second season. It is worthy noting that climatic conditions played a major role in reducing Giza 40 ability to resist chocolate spot disease at 85 to 115 days after sowing in both seasons. However, the genetic potential of the other faba bean genotypes were more acclimatized with climatic conditions for maintaining their resistance to this disease at the same period in both seasons, except Atona genotype in the second season. These results reveal that all the studied genotypes maintained their ability to resist chocolate spot infection under natural field conditions in both seasons except Giza 40 and Atona. These genotypes constitute an interesting genetic source for future breeding programs to develop chocolate spot-resistant cultivars. Thus, genetic resistance against pathogens is highly race-specific [34]. These findings are in harmony with those of Yitayih and Azmeraw [32].

Maturity date, seed yield and its attributes

Data in table 8 show that there were significant differences among genotypes in maturity date, seed yield and its attributes in both seasons, except number of branches per plant in both seasons, plant height and number of pods per plant in the second season. In general, faba bean genotypes Sakha 4, Sakha 1 and Santamora are early - maturing genotypes, and faba bean genotypes L2, Nubaria 1 and Misr 3 late - maturing ones in both seasons.

There was a remarkable significant difference in plant height among genotypes. Giza 843, Giza 40, L3 and L4 gave the taller plants (123.33, 115.00, 117.66 and $116.66 \mathrm{~cm}$, respectively). However, L1 $(90.33 \mathrm{~cm})$, Santamora $(95.00 \mathrm{~cm})$, Sakha 4 (96.66 cm), Sakha 1 $(98.33 \mathrm{~cm})$ and Misr $3(98.33 \mathrm{~cm})$ gave shorter ones compared with the other genotypes in the first season. These results could be attributed to increasing internode number and elongation of Giza 843, Giza 40, L3, and L4 due to genetic differences that interacted with day length. Moreover, as faba bean plant becomes taller, selfshading is enhanced and there may be an exceedingly steep light gradient between the top and bottom of the plant. These results are in accordance with those of Abbas., et al. [35]. Also, Mohamed., et al. [36] showed that Sakha 1 plants were taller than Masr 3.

Sakha 4, Sakha 1, Giza 3, Sakha 3, L2 and L3 genotypes produced greater pods/plant, whereas Atona and Giza 40 gave lower number in the first season. These results probably attributed to plants of Sakha 4, Sakha 1 and L3 had a shorter vegetative growth phase and a shorter reproductive phase (Figure 1) that largely contributed to leaf chlorophyll content (Figure 3) which was reflected positively on their resistance to rust and chocolate spot diseases at 85 through 115 days after sowing in the first season (Table 6 and 7).

Faba bean cultivars Giza 3 and Sakha 3 had higher content of chlorophyll pigments and resistance to rust and chocolate spot diseases, this biological situation may be positively reflected on the photosynthetic potential of those genotypes, resulting in more pods per plant in the first season. With regard to faba bean genotype L2, this genotype had longer flowering period, higher content of chlorophyll pigments and resistance to rust and chocolate spot diseases in the first season that played a major role in increasing number of pods per plant. 


\begin{tabular}{|c|c|c|c|c|c|c|}
\hline \multirow{2}{*}{$\begin{array}{c}\text { Faba bean } \\
\text { genotype }\end{array}$} & $\begin{array}{l}\text { Maturity } \\
\text { (day) }\end{array}$ & $\begin{array}{l}\text { Plant height } \\
\text { (cm) }\end{array}$ & $\begin{array}{c}\text { Number of branches per } \\
\text { plant }\end{array}$ & $\begin{array}{c}\text { Number of pods per } \\
\text { plant }\end{array}$ & $\begin{array}{l}\text { Seed yield/ } \\
\text { plant (g) }\end{array}$ & $\begin{array}{l}\text { Seed yield } / \text { ha } \\
\text { (ton) }\end{array}$ \\
\hline & \multicolumn{6}{|c|}{ First season } \\
\hline Giza 40 & 156.66 & 115.00 & 2.66 & 12.21 & 24.33 & 3.03 \\
\hline Atona & 150.00 & 101.66 & 2.00 & 8.33 & 31.66 & 3.90 \\
\hline Giza 3 & 153.33 & 108.33 & 3.00 & 17.36 & 51.40 & 4.00 \\
\hline Sakha 1 & 136.66 & 98.33 & 2.66 & 18.33 & 45.46 & 5.49 \\
\hline Misr 1 & 155.00 & 108.33 & 2.00 & 13.30 & 33.83 & 5.08 \\
\hline Santamora & 146.66 & 95.00 & 2.33 & 12.16 & 62.33 & 4.93 \\
\hline Misr 3 & 160.00 & 98.33 & 2.00 & 13.10 & 36.00 & 4.43 \\
\hline Giza 843 & 153.33 & 123.33 & 2.33 & 12.56 & 43.36 & 4.69 \\
\hline Sakha 3 & 145.00 & 110.00 & 2.00 & 15.00 & 42.20 & 5.34 \\
\hline Sakha 4 & 135.00 & 96.66 & 2.33 & 18.60 & 47.10 & 5.64 \\
\hline Nubaria 1 & 161.66 & 100.00 & 2.66 & 10.76 & 36.33 & 4.14 \\
\hline L 1 & 153.33 & 90.33 & 2.66 & 11.83 & 36.96 & 4.58 \\
\hline $\mathrm{L} 2$ & 168.33 & 101.66 & 2.33 & 14.80 & 38.56 & 5.23 \\
\hline L 3 & 145.00 & 117.66 & 2.33 & 15.40 & 41.70 & 5.50 \\
\hline $\mathrm{L} 4$ & 158.33 & 116.66 & 2.33 & 12.33 & 40.41 & 3.42 \\
\hline L.S.D. 0.05 & 12.55 & 9.97 & N.S. & 4.74 & 23.42 & 1.21 \\
\hline $\begin{array}{l}\text { Faba bean } \\
\text { genotype }\end{array}$ & \multicolumn{6}{|c|}{ Second season } \\
\hline Giza 40 & 148.33 & 120.00 & 2.50 & 8.61 & 20.95 & 2.92 \\
\hline Atona & 153.33 & 108.33 & 2.76 & 7.33 & 31.08 & 2.94 \\
\hline Giza 3 & 158.33 & 113.33 & 2.75 & 7.89 & 20.42 & 3.20 \\
\hline Sakha 1 & 138.33 & 123.33 & 2.16 & 10.88 & 25.89 & 4.40 \\
\hline Misr 1 & 160.00 & 116.66 & 1.75 & 11.73 & 23.61 & 3.80 \\
\hline Santamora & 147.66 & 116.66 & 2.25 & 17.75 & 61.66 & 5.46 \\
\hline Misr 3 & 156.66 & 126.66 & 1.93 & 10.19 & 19.19 & 3.89 \\
\hline Giza 843 & 158.33 & 126.66 & 2.03 & 10.88 & 27.45 & 5.61 \\
\hline Sakha 3 & 145.00 & 106.66 & 1.81 & 12.44 & 26.22 & 5.34 \\
\hline Sakha 4 & 135.00 & 123.33 & 2.13 & 10.75 & 25.36 & 5.39 \\
\hline Nubaria 1 & 160.00 & 116.66 & 2.33 & 10.44 & 23.42 & 3.66 \\
\hline L 1 & 165.00 & 130.00 & 2.33 & 9.33 & 17.10 & 3.77 \\
\hline L 2 & 160.00 & 123.33 & 1.96 & 8.55 & 20.41 & 5.52 \\
\hline L 3 & 151.66 & 136.66 & 1.75 & 9.33 & 27.47 & 4.93 \\
\hline L 4 & 153.33 & 120.00 & 2.41 & 10.72 & 22.14 & 4.49 \\
\hline L.S.D. 0.05 & 8.44 & N.S. & N.S. & N.S. & 25.13 & 1.35 \\
\hline
\end{tabular}

Table 8: Maturity, seed yield and its attributes of 15 faba bean genotypes in 2017/2018 and 2018/2019 seasons.

Although Santamora genotype had shorter flowering period and higher chlorophyll content, it was moderately resistant to rust and resistant to chocolate spot infection in the first season. This could have improved the photosynthetic potential of the genotype and led to more new pod development. Meanwhile, leaves of Giza
40 cultivar were susceptible to chocolate spot infection than the other genotypes at 115 days in the first season (Table 7) and this susceptibility led to adverse effect on the number of pods per plant. However, it seems that lower content of chlorophyll a and total chlorophyll in leaves of Atona genotype had a negative effect on 
the photosynthetic potential that was responsible for reducing the number of pods per plant. So, it is likely that the genetic potential of Sakha 4, Sakha 1, Giza 3, Sakha 3, L2 and L3 genotypes interacted positively with environmental conditions for inducing their resistance to rust or chocolate spot diseases through maintaining their chlorophyll pigments (Figure 3) and more pods development than the other genotypes. These results are in accordance with Abbas., et al. [35] who indicated that Giza 716 cultivar gave the highest values of number of pods per plant compared with the others.

With respect to seed weight per plant, Santamora, Giza 3, Sakha 4, Sakha 1, Giza 843, Sakha 3, L3, and L4 had higher seed weight per plant, recording 62.33, 51.40, 47.10, 45.46, 43.36, 42.20, 41.70 and $40.41 \mathrm{~g}$, respectively, in the first season. This is attributed to those genotypes had a higher number of pods per plant that contributed largely in their productivity. It is important to mention that faba bean genotypes Sakha 4, Sakha 1 and Sakha 3 were highly resistant to chocolate spot infection at 85 days and resistant to this disease at 115 days in the first season. Moreover, faba bean genotype Sakha 4 was resistant to rust infection at 85 and 115 days after sowing, meanwhile, faba bean genotypes Sakha 1 and Sakha 3 were resistant and moderately resistant to rust infection at 85 and 115 days after sowing, respectively in the first season. With respect to faba bean genotype Giza 3, it was resistant to chocolate spot infection at 85 days and moderately resistant to this disease at 115 days in the first season. With regard to faba bean genotype L3, it was highly resistant to chocolate spot and resistant to rust infection at 85 and 115 days after sowing, respectively, in the first season. However, L4 and Santamora genotypes were resistant to chocolate spot and moderately resistant to rust infection at 85 and 115 days from sowing in the first season.

In the second season, Santamora genotype had the highest seed weight per plant (61.66 g) compared with the other genotypes. These results may be due to the genetic potential of this genotype interacted positively with environmental conditions to enhance its photosynthetic potential that positively reflected on its productivity. However, Giza 40 and Atona genotypes gave lower seed yield per plant than the other genotypes probably due to their susceptibility to rust and chocolate spot diseases that had adverse effects on their productivity. It is worthy to note that Giza 40 genotype was more susceptible to rust and chocolate spot diseases in the first season. Although resistance of faba bean genotypes differed directly or indirectly with seasonal shift due to fluctuating climatic conditions, these genotypes may produce high yield under low and moderate infection or even under high infection of foliar diseases.
Abbas., et al. [35] reported that Giza 716 cultivar gave the highest seed weight per plant compared with the others.

With respect to seed yield per ha, Sakha 4, L3, Sakha 1, Sakha 3, L2, Misr 1, Santamora and Giza 843 had higher seed yield per ha (5.64, 5.50, 5.49, 5.34, 5.23, 5.08, 4.93 and 4.69 ton, respectively), meanwhile, the opposite trend was achieved by faba bean genotypes Giza 40 (3.03 ton), L4 (3.42 ton), Atona (3.90 ton), and Giza 3 (4.00 ton) in the first season. In the second season, Giza 843, L2, Santamora, Sakha 4 and Sakha 3 genotypes recorded higher seed yield per ha (5.61, 5.52, 5.46, 5.39 and 5.34 ton, respectively). However, lower seed yields per ha were recorded by Giza 40 (2.92 ton) and Atona (2.94 ton). Generally, Santamora, L2, Giza 843, Sakha 4, and Sakha 3 genotypes recorded higher seed yields per ha than the other genotypes in both seasons. This may be due to higher seed weight per plant as a result of their higher resistance to rust and chocolate spot diseases under natural field conditions [37]. On the contrast, Giza 40 and Atona genotypes gave lower seed yields per ha than the other genotypes due to their higher susceptibility to rust and chocolate spot diseases. These results are in parallel with those of Abbas., et al. [35]. Also, Mohamed., et al. [36] showed that faba bean cultivar Sakha 1 had higher seed yield per ha than Masr 3 cultivar.

\section{Simple correlation coefficient}

Simple correlation coefficient in table 9 showed the interrelationships among days to $50 \%$ flowering, foliar diseases, maturity date and seed yield, as well as its attributes. It is obvious that that significant positive correlation was obtained between maturity date and each of days to $50 \%$ flowering $(r=0.532 *)$, rust disease $\left(\mathrm{r}=0.505^{*}\right)$ and chocolate spot $\left(\mathrm{r}=0.551^{*}\right)$. Meanwhile, there is a highly negative correlation between maturity date and each of number of pods per plant $\left(\mathrm{r}=-0.592^{* *}\right)$, seed yield per plant $(\mathrm{r}$ $\left.=-0.878^{* *}\right)$ and seed yield per ha $\left(\mathrm{r}=-0.747^{* *}\right)$. Also, there is a significant positive correlation was obtained between days to $50 \%$ flowering and each of rust disease $\left(r=0.514^{*}\right)$ and chocolate spot $\left(\mathrm{r}=0.578^{*}\right.$ ). Meanwhile, there is a highly negative correlation between days to $50 \%$ flowering and each of number of pods per plant $\left(\mathrm{r}=-0.597^{* *}\right)$, seed yield per plant $\left(\mathrm{r}=-0.892^{* *}\right)$ and seed yield per ha $\left(r=-0.766^{* *}\right)$. Also, there is a negative correlation between rust disease and each of number of pods per plant $\left(-0.564^{*}\right)$, seed yield per plant $\left(\mathrm{r}=-0.844^{* *}\right)$ and seed yield per ha $\left(\mathrm{r}=-0.798^{* *}\right)$. Moreover, there is a negative correlation between chocolate spot disease and each of number of pods per plant $\left(-0.533^{*}\right)$, seed yield per plant $\left(r=-0.889^{* *}\right)$ and seed yield per ha $\left(r=-0.742^{* *}\right)$. 


\begin{tabular}{|c|c|c|c|c|c|c|c|c|c|}
\hline Traits & 1 & 2 & 3 & 4 & 5 & 6 & 7 & 8 & 9 \\
\hline Maturity date & 1 & & & & & & & & \\
\hline Days to $50 \%$ flowering & $0.532 *$ & 1 & & & & & & & \\
\hline Rust & $0.505^{*}$ & $0.514^{*}$ & 1 & & & & & & \\
\hline Chocolate spot & $0.551^{*}$ & $0.578^{*}$ & 0.166 & 1 & & & & & \\
\hline Plant height & -0.167 & -0.105 & -0.118 & -0.173 & 1 & & & & \\
\hline Number of branches/plant & -0.202 & -0.126 & -0.224 & -0.118 & 0.193 & 1 & & & \\
\hline Number of pods/plant & $-0.592 * *$ & $-0.597 * *$ & $-0.564^{*}$ & $-0.533^{*}$ & 0.165 & 0.156 & 1 & & \\
\hline Seed yield/plant & $-0.878^{* *}$ & $-0.892^{* *}$ & $-0.844^{* *}$ & $-0.889 * *$ & 0.276 & 0.216 & $0.693^{* *}$ & 1 & \\
\hline Seed yield//ha & $-0.747^{* *}$ & $-0.766^{* *}$ & $-0.798^{* *}$ & $-0.742^{* *}$ & 0.109 & 0.302 & $0.728^{* *}$ & $0.894^{* *}$ & 1 \\
\hline
\end{tabular}

Table 9: Simple correlation coefficient among faba bean traits, combined data across the two seasons.a

Conversely, there is a positive correlation between number of pods per plant and each of seed yield per plant $\left(r=0.693^{* *}\right)$ and seed yield per ha $\left(r=0.782^{* *}\right)$. Finally, there is a highly positive correlation between seed yield per plant and seed yield per ha $\left(\mathrm{r}=0.894^{* *}\right.$ ). Positive correlations between yield attributes are consider significance to the breeder, because component breeding could be very effective under these conditions.

The correlation indicate that, selection for genotypes with ruts and chocolate spot disease resistant and high number of pods per plant should be expected to result in high yielding genotypes. This plays an important role to breeders to find new genotypes characterized by foliar disease resistance associated with high yielding potentiality. Similar results were obtained by Hamdi., et al. [38] and Abou-Zeid [39]. Also, El-Sayed., et al. [40] observed that there is a high negative significant correlation between the disease progress curve and yield of five tested cultivars in the two seasons. They added that there is a high negative correlation between disease severity and each of number of pods per plant and weight of pods of Giza 40 and Sakha 1. Moreover, Abbas., et al. [35] reported that a positive and significant correlation was obtained between seed yield/fad and each of number of pods/plant and seed weight/ plant. They added that seed weight/plant was significantly correlated with number of pods/plant.

\section{Conclusion}

It can be concluded that proper utilization of plant genetic factors will help in developing cultivars with a high level of rust and chocolate spot resistance. Our observations for faba bean are evidence that Uromyces fabae and Botrytis fabae are markedly different in their virulence toward the studied faba bean genotypes. Faba bean genotypes Santamora, L2, Giza 843, Sakha 4, and Sakha
3 could be constituted as an interesting genetic sources for future breeding programs for developing rust and chocolate spot-resistant cultivars. Selection would not be effective to improve faba bean genotypes for resistance to rust and chocolate spot diseases when depending on the risk of the fungal in a particular year. Continuous crop breeding for developing better resistant cultivars is the only choice to ensure sustainable production. Good understanding of the disease resistance mechanism on host plant and the pathogen virulence are needed to breed for disease resistance.

\section{Conflict of Interest}

No declare for financial interest or any conflict of interest exists.

\section{Bibliography}

1. Sharaan AN., et al. "Seed yield, yield components and quality character as affected by cultivars, sowing dates and planting distances in faba bean". Bulletin Agriculture Economic Ministry Egypt (2004).

2. Al-Ghamdi SS. "Genetic behavior of some selected faba bean genotypes". African Crop Science Society Conference, El-Minia, Egypt 8 (2007): 709-714.

3. Burstin J., et al. "Improving protein content and nutrition quality (Chapter 20)". In A. Pratap, and J. Kumar (Eds.), Biology and breeding of food legumes. New Delhi, India, CABI (2011): 314328.

4. FAOSTAT. "World statistics on faba bean". Food and Agriculture Organization of the United Nations (2017).

5. FAOSTAT. "World statistics on faba bean". Food and Agriculture Organization of the United Nations (2018). 
6. Ibrahim AA., et al. "Production and improvement of grain legumes in Egypt". In: Hawtin G.C. and Chancellor G.C. (Eds.). Food legume Improvement and Development Workshop, held at the University of Aleppo ICARDA, Aleppo, Syria (1979): 3946.

7. Harrison JG. "The biology of Botrytis spp. on vicia beans and chocolate spot disease a review". Plant Pathology 37.2 (1988): 468-2010.

8. Bernier CC., et al. "Field manual of common faba bean diseases in the Nile Valley". International Center for Agricultural Research in Dry Areas (ICARDA) information Bulletin No. 3 (1993).

9. Khalil SA., et al. "Breeding for high yielding ability with improved level of resistance to chocolate spot (Botrytis fabae) disease in faba bean (Vicia faba L.)". Journal of Agricultural Sciences, Mansoura Univ., 18.2 (1993): 1315-1328.

10. Khaled AA., et al. "Chemical control of some faba bean disease with fungicides". Egyptian Journal of Agricultural Research 73 (1995): 45-56.

11. Nassib AM., et al. "Breeding research in Egypt". Report on the first phase of NVP. ICARD/IFAD (1983): 60-63.

12. Stoddard FL and Herath I. "Genetic analysis of partial rust resistance in faba bean”. Australian Journal of Agricultural Research 52 (2001): 73-84.

13. Bouhassan A., et al. "Evaluation of a collection of faba bean ( Vicia faba L.) genotypes originating from the Maghreb for resistance to chocolate spot (Botrytis fabae) by assessment in the field and laboratory". Euphytica 135 (2004): 55-62.

14. Awaad HA., et al. "Assessement of some genetic parameters for resistance to leaf miner, chocolate, rust and yield of faba bean in F3 and F4 generations". Egyptian Journal of Plant Breeding 9.1 (2005): 1-15.

15. El-Bramawy MAS. and Abdul Wahid O.A. "Faba bean sources of resistance to chocolate and spot diseases, earliness and seed yield". The $7^{\text {th }}$ ACSS Conference, Uganda, 7 (2005): 359-562.

16. Silleroa JC., et al. "Characterization of new sources of resistance to Uromyces viciae-fabae in a germplasm collection of Vicia faba". Plant Pathology 49 (2000): 389-395.
17. Torres AM., et al. "Faba bean breeding for resistance against biotic stresses: Towards application of marker technology". Euphytica 147 (2006): 67-80.

18. ICARDA. "Impact of improved faba bean technologies in Africa No. 2". International Center for Agricultural Research in the Dryland Areas (2008).

19. Sinha SK and Ghildiyal MC. "Variability in Photosynthesis and Nitrogen Fixation in Mungbean and Cowpea Cultivars". In: Physiological Studies on Pulses, Sirohi, G.S. (Ed.). IARI, New Delhi (1971): 38-42.

20. Hendawey MH and Younes AMA. "Biochemical evaluation of some faba bean cultivars under rainfed conditions at ElSheikh Zuwayid". Annals of Agricultural Science, 58.2 (2013): 183-193.

21. Abd El-Razek UA., et al. "Effect of certain micronutrients on some agronomic characters, chemical constituents and alternaria leaf spot disease of faba bean". Asian Journal of Crop Science 5 (2013): 426-435.

22. Podlesny J., et al. "Occurrence of fungal diseases caused by fungi on faba bean (Vicia faba L. var. minor Harz.) plants in different regions of Poland". Progress in Plant Protection 57 (2017): 190-195.

23. Waly FE., et al. "Evaluation of some faba bean cultivars yield under chemical control to common insect pests and fungal diseases under El-Beheira Governorate environmental conditions". Journal of Plant Production, Mansoura Univ., 10.2 (2019): 107-116.

24. Holden M. "Chlorophyll". In: Goodwin, T.W., Ed., Chemistry and Biochemistry of Plant Pigments, Academic Press, London (1965), 462-488.

25. Hanouniuk SB. "Screening Techniques for Disease Resistance in Faba Bean". International Center for Agricultural Research in the Dry Areas (ICARDA), Aleppo, Syria (1986): 59.

26. Freed RD. "MSTATC Microcomputer Statistical Program". Michigan State University, East Lansing, Michigan, USA (1991).

27. Gomez KA and Gomez AA. "Statistical Procedures for Agricultural Research". $2^{\text {nd }}$ edition, John Willey and Sons, Toronto, ON, Canada (1984). 
28. El-Rodeny WM., et al. "Investigation of chocolate spot and rust resistance in Egyptian faba bean population using morphological traits and molecular markers". Agrociencia 54.2 (2020): 15-30.

29. Rotem J and Aust HJ. "The effect of ultraviolet and solar radiation and temperature on survival of fungal propagules". Journal of Phytopathology 133 (1991): 76-84.

30. Asthana A and Tuveson RW. "Effects of UV and phototoxins on selected fungal pathogens of citrus". International Journal of Plant Science 153 (1992): 442-452.

31. Pulse Breeding Australia. "Southern/Western Faba and Broad Bean-Best Management Practices Training Course". Module 6-Disease Management (2013).

32. Yitayih G and Azmeraw Y. "Evaluation of faba bean varieties against chocolate spot (Botrytis fabae Sard) disease at Farta, South Gondar, Ethiopia". Journal of Crop Science and Biotechnology 21.1 (2018): 35-41.

33. Chakraborty S., et al. "Climate change: potential impact on plant diseases”. Environmental Pollution 108.3 (2000): 317326.

34. Keller B., et al. “Genetics of Disease Resistance”. In Mechanisms of resistance to plant diseases, Springer (2000): 101-160.

35. Abbas El-EI., et al. "Productivity and chocolate spot and rust diseases of some faba bean cultivars under different sowing dates and salicylic acid concentrates". Journal of Plant Protection and Pathology 3.8 (2012): 793-810.

36. Mohamed HFY., et al. "Influences of ridge width and foliar spraying of amino acids compounds on yield and quality of two faba bean cultivars". Agricultural Sciences 9 (2018): 16291651.

37. Saxena MC and Stewart RA. "Faba bean in the Nile Valley". Report on the first phase of the ICARDA/IFAD Nile Valley Project (1972-82). Martinus Nijhoff, the Hague, the Netherlands (1983): 151.

38. Hamdi A., et al. "Performance of some F3, F4 and F5 segregants in relation to chocolate spot disease resistance in faba bean". Egyptian Journal of Applied Sciences 18.7 (2003): 32-46.
39. Abou-Zeid NM. "Screening the regional chocolate spot nursery for resistance". National Coordination Meeting, Cairo, Egypt (2006).

40. El-Sayed AS., et al. "Fungicidal management of chocolate spot of faba bean and assessment of yield losses due to the disease". Annals of Agricultural Sciences 56.1 (2011): 27-35.

\section{Assets from publication with us}

- Prompt Acknowledgement after receiving the article

- Thorough Double blinded peer review

- Rapid Publication

- Issue of Publication Certificate

- High visibility of your Published work

Website: www.actascientific.com/

Submit Article: www.actascientific.com/submission.php

Email us: editor@actascientific.com

Contact us: +919182824667 